\title{
Optical coherence tomography in presumed subretinal Toxocara granuloma: case report
}

\author{
Tomografia decoerência óptica em granuloma sub-retiniano porToxocara: \\ relatodecaso
}

\author{
Aline do Lago ${ }^{1}$ \\ Rafael Andrade ${ }^{2}$ \\ Cristina Muccioli ${ }^{3}$ \\ Rubens Belfort $\mathbf{J r}^{4}$
}

Vision Institute, Department of Ophthalmology, Federal University of São Paulo - UNIFESP - Brazil.

${ }^{1}$ Medical Doctor (MD) at Universidade Federal de São Paulo - UNIFESP, São Paulo (SP) - Brasil.

${ }^{2}$ Medical Doctor (MD) at UNIFESP, São Paulo (SP) Brasil.

${ }^{3}$ Medical Doctor (MD) at UNIFESP, São Paulo (SP) Brasil.

${ }^{4}$ Medical Doctor (MD), PhD, at UNIFESP, São Paulo (SP) - Brasil

None of the authors has a proprietary interest in any of the products mentioned in this article.

Addres to correspondence: Aline do Lago - Rua Sena Madureira, 1265, apt. 51, São Paulo (SP) - Brazil CEP 04021-051

E-mail: alinelago@oftalmo.epm.br

Recebido para publicação em 31.03.2005

Versão revisada recebida em 02.11.2005 Aprovação em 13.12.2005

Nota Editorial: Depois de concluída a análise do artigo sob sigilo editorial e com a anuência do Dr. Walter Yukihiko Takahashi sobre a divulgação de seu nome como revisor, agradecemos sua participação neste processo.

\begin{tabular}{|l|}
\hline ABSTRACT \\
\hline Our aim was to study optical coherence tomographic findings in a case \\
of Toxocara granuloma. A patient with a cicatricial macular lesion, \\
diagnosed as ocular toxocariasis, was examined with optical coherence \\
tomography. In optical coherence tomography images, the macular \\
granuloma appeared as a highly reflective round mass protruding above \\
the retinal pigment epithelium with two other surrounding masses. \\
Optical coherence tomography may increase understanding of the patho- \\
physiology of the retinal Toxocara granuloma and help in the clinical \\
diagnosis and management of its macular complications.
\end{tabular}

Keywords: Granuloma/diagnosis; Retinal diseases; Eye infections, parasitic; Tomography, optical coherence/methods; Toxocara; Case reports [publication type]

\section{INTRODUCTION}

Visceral larva migrans was first described by Beaver et al., to define a clinical syndrome of man characterized by hepatomegaly, fever, chronic eosinophilia and hypergammaglobolulinemia ${ }^{(1)}$. The common roundworms, Toxocara canis and Toxocara cati are still the most frequently incriminated agents.

Transmission to human beings occurs by ingestion of contaminated soil or eggs on hands and fomites. Direct contact with infected dogs and cats plays a secondary role in transmission because eggs need an extrinsic period to become infective. Neither worms nor eggs are eliminated in human feces and because larvae are difficult to detect in tissues, diagnosis is mostly based on serology $\mathrm{y}^{(2)}$.

There are two forms of ocular Toxocara: visceral and ocular. Ocular toxocariasis is rare and therefore the spectrum of clinical disease is difficult to establish ${ }^{(3)}$. Toxocara canis is a nematode infection with potentially serious consequences for vision ${ }^{(4)}$, and is typically found in children below the age of sixteen ${ }^{(5)}$.Wilkinson and Welch classificated ocular Toxocara into: difuse endophtalmitis, posterior pole granuloma and peripheral ${ }^{(6)}$.

Probably the most common presentation is the granuloma found in the posterior pole or at the periphery ${ }^{(7)}$. Standard diagnostic methods for ocular Toxocara are fundoscopy, ultrasound and serologic tests. We studied the features of a presumed subretinal Toxocara granuloma using optical coherence tomography - OCT.

\section{CASE REPORT}

A 5-year-old boy with eye deviation for nine months was referred for examination. Both physical examination and a complete blood cell count 
with differential count were normal. Visual acuity was 20/20 in the right eye and counter fingers at $1 \mathrm{~m}$ in the left eye and a medium angle endotropia was noticed. The anterior segment was quiet and the intraocular pressure was normal. An illdefined whitish elevated lesion associated to smaller satellite lesions with a serous retinal detachment were observed in the macula of the left eye (Figure 1). No abnormalities were found in the right eye.

The patient's pupils were dilated with $0.5 \%$ cyclopentolate and $2.5 \%$ phenylephrine eye drops instilled at least 30 minutes before examination. Topical anesthetic eye drops $(0.1 \%$ proximetain cloridate) were instilled immediately before examination. After the examination, the patient was submitted to OCT evaluation. The fovea was measured four times for the 6 radial scans. Fundoscopy, classification and OCT were performed on the same day.

Upon OCT examination, a central highly reflective subretinal round mass and another one smaller satellite mass structure, surrounded by subretinal fluid, were seen protruding above the retinal pigment epithelium in the macular area of the left eye (Figure 1).

A clinical diagnosis of ocular toxocariasis was made and confirmed by the presence of circulating IgG antibodies by the enzyme-linked immunosorbent assay (ELISA).

\section{DISCUSSION}

Recently it was demonstrated that the OCT is useful for the differential diagnosis between subretinal Toxocara granuloma and idiopathic choroidal neovascularization ${ }^{(8)}$.

The Toxocara larva is known to migrate across the retina, but the layer in which it migrates and its effect on the retina was unknown ${ }^{(9)}$. OCT images of our patient demonstrated that the presumed Toxocara granuloma had a subretinal extension with elevation and an ill-defined yellowish border associated with atypical smaller satellite lesions as well as serous retinal detachment. The foveal involvement was clearly demonstrated by optical coherence tomography (Figure 2A). Crosssectional optical coherence tomography images may increase understanding of the pathophysiology of presumed subretinal Toxocara granulomas and help in the clinical management of the retinal complications related to this disease.

\section{RESUMO}

Estudar os achados em tomografia de coerência óptica num caso de granuloma por Toxocara. Paciente com uma lesão macular cicatricial no olho esquerdo foi submetido a retinografia e tomografia de coerência óptica. Nas imagens de tomografia de coerência óptica, o granuloma aparece como uma imagem de uma massa arredondada hiper-reflectiva acima do epitélio pigmentar e abaixo da retina neurossensorial acompanhado de duas lesões satélites menores. A tomografia de coerên-

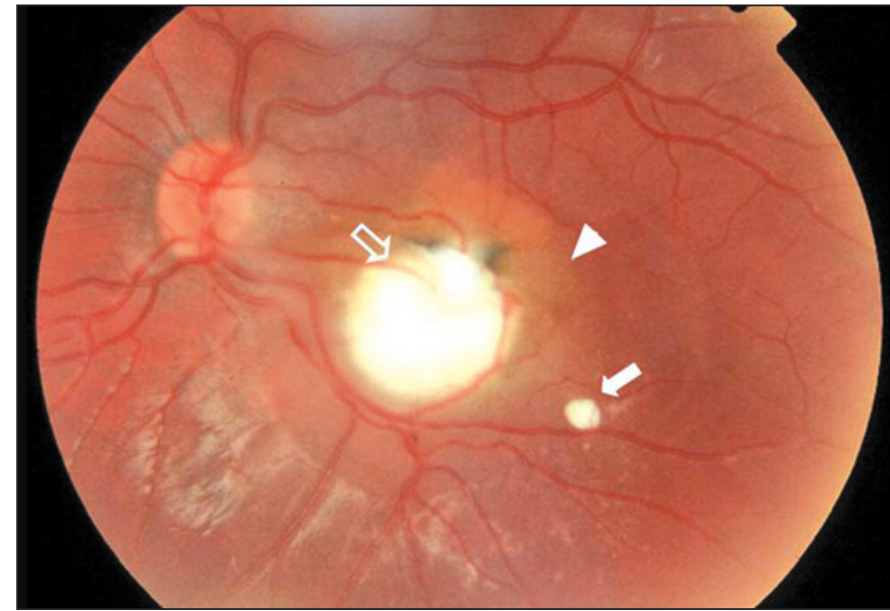

Figure 1 - Fundus photograph of the posterior pole of the left eye shows a large whitish elevated lesion (open arrow) with an ill-defined yellowish temporal border (arrowhead) associated with a smaller satellite lesion (arrow). Pigment hypertrophy and surrounding subretinal fluid were observed.

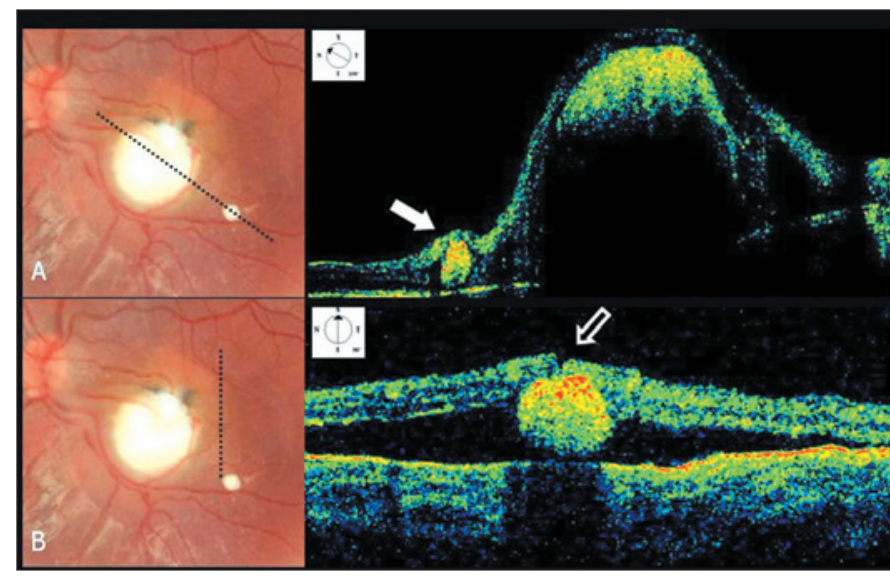

Figure 2 - A: OCT scan reveals an elevated large subretinal lesion with serous retinal detachment associated with a smaller satellite lesion (arrow); B: OCT shows in a macular vertical scan a highly reflective subfoveal spherical mass protruding above the retinal pigment epithelium with posterior shadow and surrounding subretinal fluid (open arrow).

cia óptica pode nos ajudar a melhorar o entendimento da fisiopatologia do granuloma retiniano do Toxocara, seu diagnóstico e conduta.

Descritores: Granuloma/diagnóstico; Doenças retinianas; Infecções oculares parasitárias; Tomografia de coerência óptica/métodos; Toxocara; Relatos de casos [tipo de publicação]

\section{REFERENCES}

1. Beaver PC, Snyder CH, Carrera GM, Dent JH, Lafferty JW. Chronic eosinophilia due to visceral larva migrans; report of three cases. Pediatrics. 1952;9(1): 7-19.

2. Nunes CM, Tundisi RN, Heinemann MB, Ogassawara S, Richtzenhain LJ Toxocariasis: serological diagnosis by indirect antibody competition ELISA Rev Inst Med Trop Sao Paulo. 1999;41(2):95-100. 
3. Gillespie SH, Dinning WJ, Voller A, Crowcroft NS. The spectrum of ocular toxocariasis. Eye. 1993;7( Pt 3):415-8. Comment in: Eye. 1993;7(Pt 6):810.

4. Molk R. Ocular toxocariasis: a review of the literature. Ann Ophthalmol. 1983; 15(3):216-9,222-7,230-1.

5. Ashton N. Larval granulomatosis of the retina due to Toxocara. Br J Ophthalmol. 1960;44:129-48.

6. Wilkinson CP, Welch RB. Intraocular toxocara. Am J Ophthalmol. 1971; 71(4):921-30.
7. Rubin ML, Kaufman HE, Tierney JP, Lucas HC. An intraretinal nematode (a case report). Trans Am Acad Ophthalmol Otolaryngol. 1968;72(6):855-66.

8. Higashide T, Akao N, Shirao E, Shirao Y. Optical coherence tomographic and angiographic findings of a case with subretinal Toxocara granuloma. Am J Ophthalmol. 2003;136(1):188-90.

9. Suzuki T, Joko, T, Akao N, Ohashi Y. Following the migration of a Toxocara larva in the retina by optical coherence tomography and fluorescein angiography. Jpn J Ophthalmol. 2005;49(2):159-61.

\section{Jornada Internacional de Glaucoma da Assaciaçãa Paranaense de Oftalmalogia*}

\section{3 a 15 de Qutubro de 2006 \\ Curitiba - PR}

\section{INFORMAÇÕES \\ Tel.: (411) 3232-4031 • E-mail: drfcabibi@mps.com.br}

*Participaçãa neste evento conta 5 pontos para a revalidação do títula de especialista em oftalmologia 